\title{
Effectiveness of Distance Learning via the Internet on Performance Level of the Setting, Spiking in Volleyball *Ayat Abdel-Halim Mohamed
}

\section{Abstract}

The reseach aimed to using distance learning via the Internet and monitor its effectiveness on skillful Performance level in volleyball (Setting, Spiking skill) for physical education female students. the researcher used the experimental method by the experimental design of one group using pre-post measurements, the study was conducted on a sample of (50) female students with $19.84 \%$ of the total population in the year 2016/2017, results indicated that distance learning via the Internet led to a higher level of skillful Performance under research in volleyball.

Keywords: Distance learning, Internet, Volleyball, Passing (Overhand, Overhead or Setting), Spiking.

\section{Introduction:}

Learning based using materials or electronic means, such as the distance learning or using the technology of education in general, it is a way of tools that support the educational process, using the latest methods in the fields of education, publishing and entertainment adoption of computers, media, storage and networks, which has increased in the consolidation of the concept of individual education or self -; where he continues to learn the learner according to his ability and his ability and speed of learning According to his previous experience and skills. [28: 34], [31: 52]

Distance learning has become a standard for the success of education in countries in general, and university education is in need of technology at the moment. Today, students are using the Internet on a regular basis. Elearning provides flexibility in time and space and supports channels of communication with students. [21: 30]

The distance learning is the use of technology and technology in education and

" Department of Sports Games Training, Faculty of Physical Education for Girls in Gizera, Helwan University, Arab Republic of Egypt.

Assiut Journal For Sport Science Arts 
harnessing it to learn the student self and collectively, starting with the techniques used for presentation in the classroom of multimedia and electronic devices, and ending with the physical components of education such as smart school and virtual classes through which the interaction of the members of the process Educational online. [4: 17]

In distance learning, students can log in from anywhere in the world to access their class materials and interact with one another. Each institution uses a specific system, but they are all similar in their ability to present course material including class syllabus, assignments, quizzes, and provide video and audio plus a whiteboard screen where the lesson is presented just like it would be on a classroom's video screen or blackboard. You can interact with instructors, access course materials and stimulate debate among your fellow students when it fits your schedule. In most courses, you must keep up with the scheduled course work. Courses are instructor led and in most instances, follow the same semester schedule as traditional courses.
All specific course information such as how to reach the instructor, what work is expected, and deadlines to turn in assignments and take tests will be found within your course site. [24]

On the other hand, Volleyball is the world's second popular sport after soccer. the United States Volleyball Association (USVBA) is the national governing body with its headquarters located in Colorado Springs, Colorado which is also the Olympic training center. The basics of the original game has changed drastically over the years. Players are now expected to achieve the more advanced skills of the game and keep abreast of the new developments. The rebound aspect of volleyball creates unique challenges for all players. Volleyball makes broad motor skill demands on a player in spatial orientation, balance, rhythm, power, speed, and other abilities. Volleyball is not a copy of experiences of any other team sport, but it is the truest team sport. [13]

Setting- Used to receive a teammate's pass in order that the play may continue by 
passing the ball overhead to an attacker. the fundamental action of setting is to contact the ball with the finger pads momentarily at the forehead and following through with arms fully extended to the hitting target. Attack (Spike)Used to put the ball into the opponent's court in order to earn a point or side out. the fundamental action of attacking incorporates a quick approach followed by a strong, full arm swing, and followthru. [14]

According to the above, this study is based using of distance learning via the Internet, which offered content of lessons for the purpose of learning Some volleyball skills, The researcher observation during her work at the Faculty of Physical Education that Methods and means used to learn volleyball skills lacks the motivation of the learner and the desire to learn more skills, as period after using these methods the learner sense monotony and boredom, these traditional methods doesn't commensurate with what the world reached of technological uses and applications in the educational process.
Therefore, this study is an attempt to teach female students with one of the most modern strategies in the field of volleyball, by using distance learning via the Internet for studying its effect on skillful performance in volleyball.

\section{Objective:}

The aim of this study was studying effect of using distance learning via the Internet on skillful Performance level in volleyball (Set, Spike skill) for female students of physical education faculty.

\section{Research hypothes:}

There are statistically significant differences between the average of the pre-and postmeasurements for research group in the level of skillful Performance under research in favor to the post measurement. Methodology Method:

The experimental approach was used for one group, using pre- post measurements.

\section{Research sample:}

The research society consisted of (252) female students of the fourth class students in faculty of physical education for girls in Gezira, Helwan university for the academic year 2016/2017. The 
basic sample was randomly selected from the female students of the research community. The total number of the sample was (50) female students with $19.84 \%$ of the total population, And (20) students of the total research community and outside the basic research sample as exploration sample. Thus, the basic sample and outside the basic research sample consisted of (70) female students by $27.78 \%$ of the total population.

\section{Tools:}

1- Data recording forms: Forms for recording the data for the research sample were prepared. (Appendix 1)

2- Tools and devices: Restameter device for measuring height and weight, distance tape measure, Bearings, medical balls, tennis balls, volleyballs, volleyball court.

3- Fitness elements tests: (Appendix 2, 3) The fitness elements tests for the Set skill and the Spike skill were identified through the following references: (Ahmed 2013) [5], (Zaki 2012) [44], (Farid et al. 2012) [16], (Mohamed, Hamdy 2005) [30], (Mohamed Alhefnawi 2013) [26], (Ayman 2006) [12], (Tarek, Ayman 2006) [41], (Mohamed, Ayman 2005) [271, (Ayat 2009, 2016) [9,10], (Ali
2014) [8], (Ahmed, Ali 2005) [31, (Marwan 2012) [23], (Ali 2010) [7] and (Rehab et al. 2013)[37].

These references were used to identify:

- Fitness elements needed to perform the skills under research.

- Measurement tests for the fitness elements (physical tests).

The experts' opinion (Appendix 7) was reviewed. The experts pointed out that the fitness elements (accuracy, strength, capacity, coordination, and flexibility) Shown in Appendix (2).

The experts also pointed to the most appropriate tests (Table 1 \& Appendix 3) for measuring these physical elements, which obtained an agreement rate higher than $75 \%$. Shown in Appendix (3).

4- Skillful tests (Set, Spike): Through the following scientific studies and references: (Ali 2014)[8], (Ahmed, Ali 2005) [3], (Ayman 2006) [12], (Tarek, Ayman 2006) [41], (Mohamed, Ayman 2005) [27], (Ayat 2009, 2016) [9,10], (Marwan 2012) [23], (Rehab et al. 2013) [37], (Afaf et al. 2014)[2] and (Mohamed, Hamdy 2005)[30] The skillful tests were determined to measure the level of performance of the Set and Spike. In addition, the expert opinion (Appendix 7) was used to determine the tests 
to measure the skills, Experts agreed to the tests of (The accuracy of setting test, straight
Spike test) as shown in Appendix (4).

Table (1)

Validity and stability of physical and skillful tests. $\mathrm{N}=\mathbf{2 0}$ (test validity), $\mathrm{N}=10$ (test stability)

\begin{tabular}{|c|c|c|c|c|c|c|c|}
\hline \multirow[t]{2}{*}{ Variables } & \multirow[t]{2}{*}{ unit } & \multicolumn{2}{|c|}{$\begin{array}{c}\text { Distinct } \\
\mathrm{N}_{1}=10\end{array}$} & \multicolumn{2}{|c|}{$\begin{array}{c}\text { Non distinct } \\
\mathbf{N}_{2}=10\end{array}$} & \multirow{2}{*}{$\begin{array}{c}\text { Mean } \\
\text { differences }\end{array}$} & \multirow{2}{*}{$\begin{array}{c}\mathrm{T} . \\
\text { value }\end{array}$} \\
\hline & & $\mathbf{M}$ & \pm SD & $\mathbf{M}$ & \pm SD & & \\
\hline Accuracy & Degree & 5.65 & 0.88 & 3.85 & 2.15 & 1.80 & $4.60 *$ \\
\hline Strength & $\mathrm{Kg}$ & 23.98 & 1.18 & 22.33 & 2.32 & 1.65 & $4.39 *$ \\
\hline Arm capacity & meter & 5.84 & 0.55 & 4.05 & 0.51 & 1.79 & $4.56 *$ \\
\hline Legs capacity & $\mathrm{Cm}$ & 27.25 & 5.26 & 18.64 & 4.55 & 8.61 & $12.58 *$ \\
\hline Coordination & Degree & 5.56 & 0.88 & 4.05 & 0.54 & 1.51 & $3.60 *$ \\
\hline Frontal flexibility & $\mathrm{Cm}$ & 8.50 & 1.36 & 6.59 & 1.25 & 1.91 & $3.72 *$ \\
\hline $\begin{array}{l}\text { Background } \\
\text { flexibility }\end{array}$ & $\mathrm{Cm}$ & 28.67 & 1.91 & 24.02 & 1.80 & 4.65 & $6.21 *$ \\
\hline Set test & Degree & 23.56 & 4.56 & 12.51 & 2.10 & 11.05 & $15.33 *$ \\
\hline Spike test & Degree & 4.20 & 1.02 & 1.22 & 0.22 & 2.98 & $5.12 *$ \\
\hline \multirow{2}{*}{ Variables } & \multirow{2}{*}{ unit } & \multicolumn{2}{|c|}{$\mathbf{1}_{\text {st }}$} & \multicolumn{2}{|c|}{$\mathbf{2}_{\mathrm{n} . \mathrm{d}}$} & \multirow{2}{*}{\multicolumn{2}{|c|}{$\mathbf{C C}$}} \\
\hline & & $\mathrm{M}$ & $\pm \mathrm{SD}$ & $\mathrm{M}$ & $\pm \mathrm{SD}$ & & \\
\hline Accuracy & Degree & 3.85 & 2.15 & 3.88 & 2.16 & \multicolumn{2}{|l|}{$0.94 *$} \\
\hline Strength & $\mathrm{Kg}$ & 22.33 & 2.32 & 22.4 & 2.35 & \multicolumn{2}{|l|}{$0.93 *$} \\
\hline Arm capacity & meter & 4.05 & 0.51 & 4.03 & 0.5 & \multicolumn{2}{|l|}{$0.95 *$} \\
\hline Legs capacity & $\mathrm{Cm}$ & 18.64 & 4.55 & 18.6 & 4.49 & \multicolumn{2}{|l|}{$0.89 *$} \\
\hline Coordination & Degree & 4.05 & 0.54 & 4.08 & 0.55 & \multicolumn{2}{|l|}{$0.91 *$} \\
\hline Frontal flexibility & $\mathrm{Cm}$ & 6.59 & 1.25 & 6.61 & 1.27 & \multicolumn{2}{|l|}{$0.92 *$} \\
\hline $\begin{array}{l}\text { Background } \\
\text { flexibility }\end{array}$ & $\mathrm{Cm}$ & 24.02 & 1.8 & 24 & 1.74 & \multicolumn{2}{|l|}{$0.92 *$} \\
\hline Set test & Degree & 12.51 & 2.1 & 12.4 & 2.44 & \multicolumn{2}{|l|}{$0.90 *$} \\
\hline Spike test & Degree & 1.22 & 0.22 & 1.2 & 0.21 & \multicolumn{2}{|l|}{$0.96^{*}$} \\
\hline
\end{tabular}

The value of t-table at a significant level $(18,0.05)=2.10$ (two directions), the t-value significant differences between (cc) at a significant level (8, $0.05)=0.738$ (two directions) Sperman It is clear from Table (1) that there are statistically the two distinct and nondistinct groups, indicating the validity of the tests. It is also evident that there is a Assiut Journal For Sport Science Arts 
correlation between the first and second applications indicating the stability of the tests.

\section{Distance learning method design:}

Distance learning method was designed via the internet as shown below:

1- Objective of Distance learning method: The distance learning method through the Internet was aimed to know its effect on the performance level of the Set, Spike skills in volleyball for female students of physical education faculty.

2- Skillful level of the research sample: The skillful aspects was determined by the tests under research (Appendix 4).

3- Distance learning method content: The distance learning method content was determined through the following scientific references (Ayman 2006) [12], (Tarek, Ayman 2006) [41], (Mohamed, Ayman 2005) [27], (Suzanne 2007) [39], (Ayat 2009, 2016) [9,10], (Rehab et al. 2013) [37], (Afaf et al. 2014) [2], (Mohamed, Hamdy 2005) [30], (Ali 2014) [8], (Ahmed, Ali 2005) [3], (Marwan 2012) [23], (Ali 2010) [7], (Zaki 2012) [44], (Farid et al. 2012) [17], (Mohamed Alhefnawi 2013)
[26], (Mahmoud 2016a,b) $[20,21]$ by including some multimedia; videos, pictures and texts in A web site contains skillful aspects of the Set and Spike skills in volleyball. The stages of the technical performance of the skills under research were described (Appendix 5, 6).

4- A web site: A web site was designed or created contain the distance learning method, http://ahmedthussaam. wixsite.c om/pecb-sports. (Appendix 8)

5- Method of teaching: The teaching method (the educational style) was used in the study was the individual or self-learning method through the use of each individual student for the Internet.

6- Site features:

- Display and download text, images, graphics and video on full screen.

- Sound control during video playback.

Repetition of images, graphics and video more than once.

- Pause during video playback.

7- The experts' opinion: The experts' opinion (appendix 7) of distance learning method and agreement was obtained on a web site was designed, and the experts agreed to 
instructions and contents of the website (appendix 8).

8- The exploratory study: The distance learning method was tested by presenting the site on the sample of the exploratory study in order to identify the clarity of the pictures, drawings and video were contained on the website. The result of this experiment was the clarity of all the contents of the distance learning method on the web.

\section{Application:}

Distance learning method was implemented on the basic study sample (50 students), as shown in table (3):

Table (2)

Time distribution of the research group

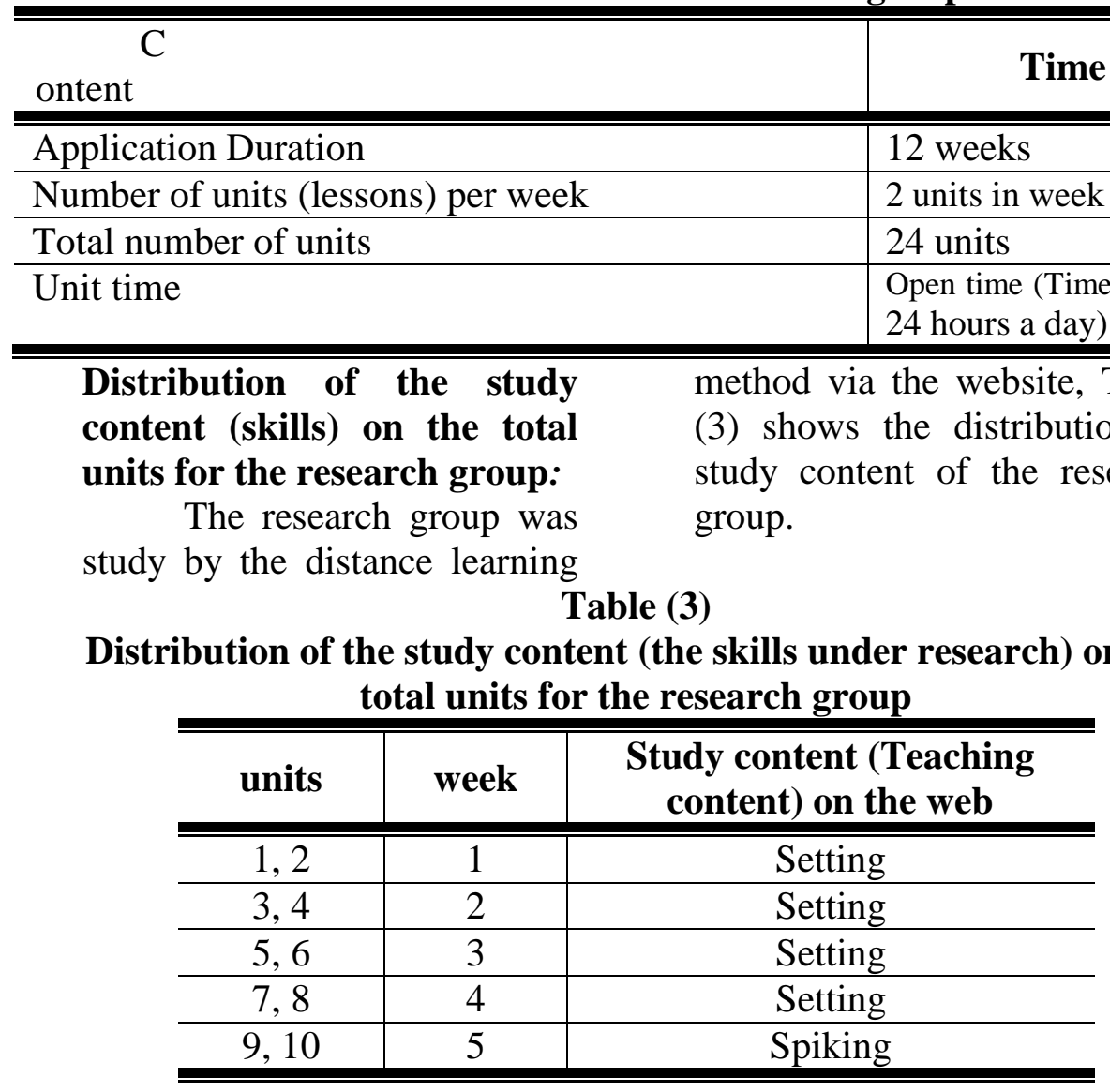

Follow Table (3)

Assiut Journal For Sport Science Arts 
Distribution of the study content (the skills under research) on the total units for the research group

\begin{tabular}{c|c|c}
\hline \hline units & week & $\begin{array}{c}\text { Study content (Teaching } \\
\text { content) on the web }\end{array}$ \\
\hline \hline 11,12 & 6 & Spiking \\
\hline 13,14 & 7 & Spiking \\
\hline 15,16 & 8 & Spiking \\
\hline 17,18 & 9 & Setting \\
\hline 19,20 & 10 & Setting \\
\hline 21,22 & 11 & Spiking \\
\hline 23,24 & 12 & Spiking \\
\hline \hline
\end{tabular}

Moderation of sample distribution:

Table (4)

Distribution moderation for basic and exploratory research sample. $N=70$

\begin{tabular}{l|c||c|c|c|c}
\hline \hline \multirow{2}{*}{\multicolumn{1}{c|}{ Parameters }} & \multirow{2}{*}{ Unit } & \multicolumn{4}{c}{ Statistical analyses } \\
\cline { 3 - 6 } & & Mean & Median & SD & SK \\
\hline \hline Age & year & 20.10 & 20.00 & 0.40 & 0.75 \\
\hline Hight & $\mathrm{Cm}$ & 162.30 & 162.00 & 1.50 & 0.60 \\
\hline Wight & $\mathrm{Kg}$ & 70.20 & 70.00 & 4.22 & 0.14 \\
\hline Physical Tests: & degree & 3.92 & 3.90 & 2.13 & 0.03 \\
\hline Accuracy & $\mathrm{Kg}$ & 22.37 & 22.5 & 2.30 & -0.17 \\
\hline Strength & meter & 4.10 & 4.00 & 0.50 & 0.60 \\
\hline Arm capacity & $\mathrm{Cm}$ & 18.66 & 19.00 & 4.52 & -0.23 \\
\hline Legs capacity & degree & 4.08 & 4.00 & 0.56 & 0.43 \\
\hline Coordination & $\mathrm{Cm}$ & 7.62 & 8.00 & 1.27 & -0.90 \\
\hline Frontal flexibility & $\mathrm{Cm}$ & 24.12 & 24.00 & 1.88 & 0.19 \\
\hline Background flexibility & \multicolumn{5}{|l}{} \\
\hline \hline Skillful Tests: & degree & 12.55 & 12.6 & 2.12 & -0.07 \\
\hline Set test & degree & 1.25 & 1.30 & 0.23 & -0.65 \\
\hline Spike test
\end{tabular}

Table (4) shows that the values of Skewness coefficients ranged from $(+3,-3)$, indicating the moderated Results distribution of the basic and exploratory sample. 
Table (5)

Significance of the mean differences between the pre- post measurements of the research group in the level of Set, Spike tests performance in volleyball

\begin{tabular}{|c|c|c|c|c|c|c|}
\hline \multirow{3}{*}{ Parameters } & \multicolumn{4}{|c|}{$\begin{array}{c}\text { Research group } \\
\text { (distance learning method) } \\
\mathrm{N}=\mathbf{5 0}\end{array}$} & \multirow{3}{*}{$\begin{array}{c}\text { Mean } \\
\text { Differences }\end{array}$} & \multirow{3}{*}{$\begin{array}{c}\text { T } \\
\text { value }\end{array}$} \\
\hline & \multicolumn{2}{|c|}{ Pre } & \multicolumn{2}{|c|}{ Post } & & \\
\hline & $\mathrm{M}$ & $\mathrm{SD} \pm$ & $\mathrm{M}$ & $\mathrm{SD} \pm$ & & \\
\hline Set & 12.54 & 2.11 & 22.30 & 5.21 & 9.76 & $14.57 *$ \\
\hline Spike & 1.19 & 0.20 & 4.10 & 0.96 & 2.91 & $4.96^{*}$ \\
\hline
\end{tabular}

$\mathrm{T}$ Table value at a significant level $(49,0.05)=1.68$ (one direction)

Table (5) shows statistically significant differences between Pre-Post measurements of the research group at a significant level of 0.05 .

\section{Discussion}

The results of Table (5) show that there are statistically significant differences between pre and post mean values of thes research group in skillful performance of Set, Spike skills at a significant level (0.05) for the post measurement.

These results indicate that the distance learning method via the website was a positive effect on the skillful level under research (Set, Spike skills). This indicates that the distance learning method led to the correct perception of how to perform skills under research. The images, drawings, texts and videos were attached to the website was a positive result on the level of skillful performance.

Also, The researcher attributed the reason for these differences to the experimental variable only, which is represented in the distance learning method via the website. The researcher also attributes the progress made to the research group to clarifying the performance of the skillful (Set, Spike skills) through The educational videos on the internet. Thus, the higher level of skillful performance for the research group.

The previous results is consistent with many studies which was indicated that use of the Internet in the educational process shows an improvement 
and effectiveness in the learning process and the higher level of skillful performance in general, such as the study of (Talha 2011)[40], (Ahmed 2011) [6], (Rania 2008) [34], (Rasha 2007) [35], (Mar Pérez et al. 2015) [22] and (Koen et al. 2015) [18].

\section{Accordingly,}

The distance learning method contribute in a positive way in improving skillful performance, and active learning using technology through the internet contributes positively to enhance skillful and physical variables under research.

On the other hand, The researcher attributes the progress of the experimental group to the interaction between the student and the learning through the Internet which the students controlled what they are subjected to and controlled the sequence of the presentation, time. As the internet help to learn according to the self-speed of each student, in addition to the formation of the optimal perception of the performance of skillful in how to emplement the skills under research through the Internet. Thus, provide the student feedback, which was helped to develop his movement perception. Therefore, the effectiveness of distance learning method via the website, This previous results is consistent with (Magdy 2003)[19], (Osman et al. 2006) [33], (Yaseen 2006) [42], (Yogesh 2004) [43], (Mohamed, Makarem, Hany, 2001) [29] and (Moustafa 2009) [32].

Accordingly, This proves that distance learning method via the Internet leads to higher level of learning and performance as a result of the practice of what has been explained and presented on the web. Thus, reflected in the level of students' performance.

Thus, A research hypothes is achieved, which stated that there are statistically significant differences between the pre-and post-measurements for the research group (distance learning method via the Internet) in the level of skillful Performance under research in favor to the post measurement.

\section{Conclusions}

Distance

learning method via the Internet has effective on the skillful performance level under research in volleyball for 
female students of physical education faculty.

\section{Recommendations}

- $\quad$ Encouraging the using distance learning method via the Internet because of its positive effect in raising the level of skillful performance in volleyball.

- Introducing learning through the internet within the curricula of the scientific subjects in the faculties of physical education.

Conducting further studies on the effectiveness of distance learning method through the Internet in other cognitive and skillful aspects.

\section{References}

\section{1- Abdel-Fattah Mahmoud El}

Ghaiti: Online e-learning and quality improvement, at http://pnnews.net/news.php?ext end.2107.16, 30 March 2016.

2- Afaf Mohamed Khattaby, Elham

Abdel-Moneim

Ahmed, Dalia Mohamed

Hashim: Applications in Volleyball, Helwan university press, Faculty of physical education, Helwan university 2014.

3- Ahmed Abdel-Daeim AlWazeer, Ali Moustafa Taha: Trainer's Guide in Volleyball (Tests, Planning, Records) Edition 2, Arab Thought House
(Dar El-Fikr El-Araby), Cairo 2005.

\section{4- Ahmed Adel Kandil:}

Teaching with modern technology, World books, Edition 2, p.17, Cairo 2014.

5- Ahmed Rady Ella-waty: "A training program for the development of traffic forecasting components and its impact on the performance level of some defense skills for volleyball players" Unpublished Master thesis, Faculty of Physical Education in Fleming, Alexandria University 2013.

\section{6- Ahmed Saher Hassanein.}

The Impact of Using the International Information

Network on Learning Some Basic Skills in Football for Students of the Second Division, Faculty of Physical Education, Menofya University. World Journal of Sport Sciences "WJSS", Vol.4 Numb. 3 , ISSN 2078 - 4724, pp:277-291. June 2011.

7- Ali Salloum Jawad alHakim: Tests, Measurement and Statistics in the sportiical Field, Edition 2, Al-Qadisiyah, Al-Teef for printing and publishing, Iraq 2010.

8- Ali Salman Abdel-Tarfi: Skillful tests in volleyball, Ministry of Higher Education 
and Scientific Research, Mustansiriya University, Iraq, at https://uomustansiriyah. edu.iq/media/lectures/13/13_20 17_10_04!09_10_59_AM.doc, 2014.

9- Ayat Abdel-Halim

Mohamed Aly: Learning by technological modeling and its effect on the performance level of Overhead Serve skill in volleyball, Scientific Journal of Sports Sciences \& Arts. (Publications; search number 110, part 2, June 2020, ISSN 1110-8460-2020-102) at www.ijssa-gezira.com. Faculty of P.E for girls, University of Helwan, 2016.

10- Ayat Abdel-Halim Mohamed Aly: "The Effect of an educational program on the level of skillful and knowledge of Spike in volleyball", Unpublished Master thesis, Faculty of Physical Education Gezera, Helwan University 2009.

11- Ayat Abdel- Halim Mohamed Aly, Eman AbdelHalim Mohamed Aly: The effect of different Teaching Styles on Learning some Volleyball Skills for Female P.E Students (Comparative Study). The international scientific Journal of Physical Education and Sport, Sciences, NSSN 24003, Print issn: 2356/9565, Online issn:
2356/9573, Volume (3), 98106, Faculty of Physical Education, Helwan University, January 2016.

12- Ayman Abdu Mohamed Mohamed: Fundamentals of Volleyball (Theory and Practice), Happy Wright for Printing and Publishing, Assiut, 2006.

13- Benjamin Franklin: Six Basic Skills of Volleyball, Franklin County Volleyball, at https://sites.google.com/a/frco. k12.va.us/fcvball/intro, 12 August 2016.

14- Benjamin Franklin: Skills of Volleyball, Franklin County Volleyball, at https://sites.google.com/a/frco. k12.va.us/fcvball/skills, $\quad 12$ August 2016.

15- Bernard Kingston, Constable \& Robinson: Advantages and Disadvantages - Why Choose Distance Learning? at https://www. thecompleteuniversityguide.co. uk/distance-learning/ advantages-and-disadvantages$\%$ E2\%80\%93-why-choosedistance-learning/, Complete University Guide (C) 2016, 5 April 2016.

16- Farid Abdel-Fattah Khashaba, Hossam Khalifa, Mahmoud Metwally:

Fundamentals of volleyball between theory and application, Rashid Press, 
second edition, Cairo, Arab Republic of Egypt. pp 45, 2012.

17- Jean Chastre, CharlesEdouard Luyt : Factors affecting the e-learning outcomes, Telematics and Informatics, Volume 32, Issue 4 , November 2015, Pages 701719.

18- Koen Aesaert, Daniël Van Nijlen, Ruben Vanderlinde, Jo Tondeur, Ines Devlieger, Johan van Braak: The contribution of pupil, classroom and school level characteristics to primary school pupils' ICT competences: A performancebased approach, Computers \& Education, Volume87, Septem ber 2015, Pages 55-69.

\section{9- Magdy Aziz Ibrahim:} Education Strategies and Learning Methods, The Anglo Egyptian Library, Cairo 2003.

20- Mahmoud Abdel-Halim Abdel-karim: School sports system - good education, teaching skills, teacher and efficiency standards, Arab Thought House (Dar El Fikr El Araby), Cairo 2016a.

21- Mahmoud Abdel-Halim Abdel-karim: School sports system - Structure and Policies, Curriculum and Curriculum, Calendar, Arab Thought House (Dar El Fikr El Araby), Cairo 2016b.
22- Mar Pérez-Sanagustín, Pedro J. Muñoz-Merino, Carlos Alario-Hoyos, Xavier Soldani, Carlos Delgado Kloos: Lessons learned from the design of situated learning environments to support collaborative knowledge construction, \& Education, Volume

87, September 2015, Pages 7082, 2015.

\section{3- Marwan Abdel-Magid} Ibrahim: Volleyball Scientific Encyclopedia (Skills, Plans, Physical and Skillful Tests), Edition 2, Al-Warraq Foundation for Publishing and Distribution, Amman, Jordan 2011, P. 198, 2012.

24- McParlin, P.: Methods of eLearning, at http://www. elearningnc.gov/about_elearnin g/methods_of_elearning/, 2 April 2016.

\section{5- Mohamed Ahmed} Mohamed El-hafnawi: The kinematic properties of Spike Serve in volleyball, at https://scholar.google.com/citat ions?user=jww5AqIAAAAJ, Faculty of Physical Education, Assiut university, 5 August 2016.

26- Mohamed Ahmed Mohamed El-hafnawi: Volleyball Training, at http://www.aun.edu.eg/arabic/ membercv.php?M_ID=3521, 
Faculty of Physical Education, Assiut university, 2013.

27- Mohamed Kamal El-din Al-Baroudei, Ayman Abdou Mohamed: The effect of use some teaching strategies in some fundamental skills of volley ball, Assiut university, Journal of Assiut for Science and Arts of Physical Education, 2005.

28- Mohamed Mohamed El Hadi: E-Learning through the Internet, Renewable Educational Horizons - I 2 977-270-902-3 ISBN, The Egyptian Lebanese Library, Cairo, 2005.

29- Mohamed Saad Zaghloul, Makarem Helmi Abu Harja, Hany Said Abdel Moneim: Education Technology and Methods in Physical Education, Book Cente, 2nd Edition, Cairo 2001.

30- Mohamed Sobhy Hassanein, Hamdy Abdel Moneim: The scientific bases of volleyball and measurement methods for evaluating (physically. Skill. Cognitive. Psychological. Analytical), book centre for publishing, second edition, Cairo. Arab Republic of Egypt. pp 34, 2005.

31- Moreno, R., Reislein, M., \& Ozogul, G.: "Using virtual peers to guide visual attention during learning." Journal of
Media Psychology: Theories, Methods, and Applications, 22(2), 52-60, 2010.

32- Moustafa Abdel-Samie Mohamed: Educational Technology, Arabic Studies, 2nd Edition, Book Center Publishing, Cairo 2009.

33- Osman Mustafa Othman, Hisham Mohamed Abdel Halim, Haitham Abdelhamid Mohamed: "The design of an educational website and its impact on some the technical, cognitive and emotional variables of the Blind sport for the physical education faculty students, Minia University" Journal of Sport Sciences and Arts, Faculty of Physical Education, Assiut University 2006.

34- Rania Mohamed Hassan: "Designing an website for field and track competitions using the internet" Third International Scientific Conferenc, Faculty of Physical Educatio, Alexandria University 2008.

35- Rasha Najih Aly: "A proposed educational program through the design of a web site model and its impact on learning some skills of rhythmic exercises for for the physical education faculty students, Minia University" unpublished PhD thesi, Faculty 
of Physical Education, Minia University 2007.

\section{6- Rehab Adel Gabal:} "Designing an educational program using the international information network and its impact on the implementation on the physical education lesson aspects in the light of the overall quality standards", Journal of Science and Sports Arts - Volume 39 - Faculty of Physical Education, Gizera, Helwan University, June 2011. 37- Rehab A. Gabal, Abdallah A. Mohamed and Khaled A. El-Battawy. "Effects of Teaching Strategy (cooperative learning and computer) on Learning the volleyball skills in P.E. Lesson". Journal of Physical Culture and Sport. Studies and Research, Warsaw, 24 ${ }^{\text {th }}$ of October 2013, Poland.

38- Simon Midgley: What is

Distance Learning? at https://www.thecompleteuniver sityguide.co.uk/distancelearning/what-is-distancelearning/, 30 March 2016.

\section{9- Suzanne Badran}

Sulaiman: Volleyball, Menoufia university press, Faculty of physical education Sadat university 2007.

40- Talha, A. Hossam El Din: "Using E-learning in learning the subject of teaching methods" Unpublished Master thesis, Faculty of Physical Education, Sadat University 2011.

41- Tarek Mohamed M. Abdel-Aziz, Ayman Abdou Mohamad Mohamad: The Effectiveness of An Educational Program Using the Computer on the Level of Skill and Feedback Among Faculty of Physical Education Volleyball Players in Assiut University, Journal of Assiut for Science and Arts of Physical Education, Volume 4, April, 2006.

\section{2- Yaseen Abdulrahman}

Kandil: Teaching aids and information technology, International Publishing House, 2rd Edition, Riyadh, Saudi Arabia 2006.

43- Yogesh Malhotra and Ranel E. Erickson. "Interactive Educational Multimedia": Coping with need for Innerving data Storage, Educational Technology, V. 34, No. 4, P. 35. 2004.

44- Zaki, M.H.:

Teaching volleyball

methods. Technical radiation library for publishing, Cairo. Arab Republic of Egypt. pp 40, 2012. 